\title{
COMPARISON OF ANALYSIS BETWEEN RECTANGULAR AND CIRCULAR OVERHEAD WATER TANK
}

\author{
Latha M. S. ${ }^{1}$ \\ ${ }^{1}$ Structural Engineering, Department of Civil Engineering, Sri Venkateshwara College of Engineering, \\ Affiliated to VTU, Bangalore, Karnataka, India. \\ e-mail: lathamsm@yahoo.co.id
}

\begin{abstract}
Water tank is a container used for the storing of liquids and they are classified based on shape and location. The overhead tank is an important and it is very common public utility structure. The study predicts the analysis and design of the rectangular and circular overhead water tank using ETABS software. The water tank is modeled and analyzed by using dynamic analysis to resist lateral loads and design is made using working stress method manually. Dead load, live load, wind load and seismic loads are applied based on IS codes. The behavior of structure for the parameters like Story drift, displacement, stiffness, deflection, storey shear, base shear, area of steel and hoop tension for circular and rectangular water tank are studied and then comparison of the results is made between circular and rectangular overhead water tank. By this study we say that the circular water tank is suitable for larger capacity and rectangular is suitable for smaller capacity and it is economical for larger capacity.
\end{abstract}

Keywords: ETABS Software; Circular; Overhead Water Tank; Rectangular

\section{INTRODUCTION}

Water tank is a container used for storing of liquids. Water is basic need for the entire living organism and is used for the drinking, irrigation, industries etc. It's essential for every individual and community to supply portable water; hence for supplying of water it is essential to store water and the stored is used for the domestic purposes. The water tank are classified based on shape and location, based on the location there are three types they are Underground water tanks, resting on ground tanks, overhead water tanks or elevated water tanks. In many cases the underground and ground resting tanks are rectangular or circular in shape and overhead water tank shapes depends on the aesthetical view and design. Based on shape there are five shapes they are circular tanks, rectangular tanks, intze tanks, square tanks, Conical or funnel shaped tanks.
For various purposes the different shapes of overhead tanks are used for storing water. Circular overhead water tank used for larger storage capacities up to 750000 litres and the height of tank will be provided up to 3 to $4.5 \mathrm{~m}$ and diameter will be up to 5 to $15 \mathrm{~m}$.

The conical shaped overhead water tanks are good in architectural feature and aesthetic, from the cast processing the slip is used to construct rapidly and will be economical. Precast concrete elements can also built using conical shaped water tank. The rectangular overhead water tanks used for small storage capacities of 50000 to 75000 litres.

The study is carried out for finding circular and rectangular overhead water tank difference for the different parameters. The behaviour of the overhead water tank is varied for loads that are gravity loads and lateral loads. The modelling of water tank and 
analysis of the water tank made using analysis software, Extended 3D (ThreeDimensional) Analysis of Building Systems, (ETABS) software.

In this study 50000 litres is considered for both the water tanks and the height of tank is provided $2.6 \mathrm{~m}$ to circular overhead water tank and $5 \mathrm{~m}$ to rectangular overhead water tank. The study of variations in behaviour of both the water tanks for different kind of parameters storey drift, storey shear, storey stiffness, base shear, displacement, area of steel, hoop tension and deflection is necessary.

\section{Background}

Several researches carried out studies on the overhead water tank and tank resting on the ground, some of the studies as follows Dogangun \& Livaoglu at (2004) studied rectangular fluid container dynamic response characteristics and investigated by using FEM. The typical rectangular fluid container is considered for the numerical analysis and the results are obtained for rigid and flexible fluid for chosen tank then it is compared with the results obtained by boundary- FEM. Soroushnia, et al. (2011), on various subsoils the seismic responses of elevated tanks with frame supporting are investigated. By considering the fixed base and elastic media for subsoil, elevated tank and subsoil system modeling is made using the FEM. The tank fluid has been modeled as lumped mass such as convective and impulsive mass and is used for fluid structure interaction to represent both the convective mass and impulsive mass. The results obtained by the modeling the elevated tanks on an elastic and fixed base medium are compared.

Soroushnia et al, (2011), past earthquakes losses happened in reservoirs and the intention for the damages happened were investigated and the patterns are provided to damage structures. The RC Elevated water tank with frame staging and shaft staging comparison is made against the lateral loads. Under one earthquake the 900 cubic meters elevated water tank is studied and analysis is made by using the dynamic time history analysis. Chaduvulaa et al, at 2013, under pure rocking elevated steel water tank behaviour is studied and investigated by experimentally for a 1:4 scale cylindrical steel elevated water tank and it's carried on shake table using various codes available on water tanks. The base shear, base moment, pressure variation in the tank is calculated by experimental results obtained and compared the parameters.

The liquid retaining structure analysis and design is made by working stress method for three cases Underground tank, resting on ground tank, and overhead Water tank (Thalapathy, et al., 2016). Using Microsoft excel sheet the analytical design is made and then comparison is made between the three cases. The analysis of Intze water tank is made and design is made based on the worst possible combination of loads, moments and shear then the deflection shape due to hydrostatic pressure and stresses are studied (Hedge, G., \& Chawhan, 2018). The circular water tank design is made using STADD.Pro software and the manual design is also done for the circular water tank (Azgar $\&$ Smruthi, 2017). They have compared some of the seismic parameters that are analyzed and manually calculated and using the result obtained with manual and designed one and they given the validation for that.

The optimum working need of rectangular and circular water tank of capacity 21000 liters is studied (Hedge, G., \& Chawhan, 2018). The analysis and design is made for both rectangular and circular water tank by using 
STAAD PRO Software and then maximum principal stress, hoop tension, area of steel and formwork comparison is made between both the water tanks. Circular water tank analysis and design is done using the STAAD.Pro Software. Accordance with IS 456:2000, SP 16, IS 801 load calculations are done and manual calculations are done known data and the seismic loading for different zones 2,3,4,5 applied and assessing the varying steel and concrete in seismic zones.

\section{Summary of background}

An overlook on all the papers the researches made analysis and design for underground rectangular and circular water tank and also for overhead water tank and they studied the seismic behavior and dynamic response characteristics and also compared both the rectangular and circular water tank and studied certain parameters and conclude that the rectangular water tank is not suitable for the larger capacities, it will be economical and circular water tank is preferred for larger capacities. From all these literature papers by considering the valuable information, in this present work analysis and design of the rectangular and circular overhead water tank has done.

\section{Objectives}

The main objectives of this project are as follows:

- To create circular and rectangular water tank models using ETABS software (Extended ThreeDimensional Analysis of Building system).

- To design rectangular and circular overhead water tank manually.

- To study the behavior of structure for the parameters like Story drift, displacement, stiffness, deflection for circular and rectangular water tank.

- To compare the results between circular and rectangular overhead water tank.

\section{METHODS}

The present work is carried out to analyze and design the water tanks, the step by step procedures involved in modeling and analysis of overhead water tank is explained as follows.

\section{Modelling}

The rectangular and circular overhead water tank modelling is carried out in ETABS software.

The table 1 shows the dimension of the rectangular overhead water tank and table 2 shows the dimension of circular overhead water tank which is calculated for the volume of 50000 liters.

[Table 1. Dimensions of rectangular water tank]

[Table 2. Dimensions of circular water tank]

Step -1: Defining material and section property

The material properties and section properties should be defined for the water tank modeling. Table 3 shows the details of the properties defining.

[Table 3. Structural data]

Step-2: Assigning the material and section property

After defining the both properties, the properties are assigned for the structure in the software.

\section{Step-3: Assigning of supports}

The fixed supports are assigned to the structure at the base to the columns after defining material and section property.

Step-4 :Defining load patterns 
The various loads acting on structure are dead load, live load, wind load, earthquake load (seismic load) and Water pressure these loads are defined.

Step-5: Assigning Loads

In ETABS software the dead load of the structure is taken directly, we need not to apply dead load again. Then other remaining loads should be assigned for the structure as per IS codes.

i. Live load $=2 \mathrm{kN} / \mathrm{m}^{2}$ per IS-875 (part 2)

ii. Seismic loads as per IS 1893 (PARTIII)

- Zone II (Bangalore)

- $Z=0.10$

- $\mathrm{I}=1.5$

- $\mathrm{R}=5$

- $\mathrm{Ta}=0.09 * \mathrm{~h} / \sqrt{\mathrm{d}}$

iii. Wind load as per IS-875 part-III

- Location $=$ Bangalore

- $\left(\mathrm{V}_{\mathrm{b}}\right) \mathrm{m} / \mathrm{sec}=33 \mathrm{~m} / \mathrm{sec}$

- $\left(\mathrm{k}_{1}\right)=1$

- $\left(\mathrm{k}_{2}\right)=1$

- $\left(\mathrm{k}_{3}\right)=1.046$

- $\left(\mathrm{V}_{\mathrm{z}}\right)=\mathrm{Vb} * \mathrm{k} 1 * \mathrm{k} 2 * \mathrm{k} 3$

- $\left(\mathrm{P}_{\mathrm{z}}\right)=0.6^{*} \mathrm{Vz}^{2}$

Step-6: Load Combinations

In ETABS the load combinations will be automatically generated and can also be defined by user. There are 26 load combinations that are defined according to IS 875 (part 5):1987 based on serviceability conditions.

After the completion of above steps the analysis is carried and then results will be obtained. Figure1 shows the model of rectangular over head water tank and Figure 2 shows the model of circular over head water tank modeled in ETABS.

[Figure 1. Rectangular Overhead Water Tank]

[Figure 2. Circular Overhead Water Tank]

\section{Step-7: Design}

After completion of analysis the results are obtainedin the software by that values the design is done manually by working stress method.

\section{RESULTS AND DISCUSSION}

As per IS codes the loads are applied and analysis is made, then designing is done for the rectangular and circular water tank by working stress method. The results obtained are plotted and discussed.

\section{Storey Drift}

Storey drift is a two consecutive stories displacement difference divided by height of that storey. The storey drift mainly depends on the height of the structure. As storey drift depends on height of structure drift value will be less if the height of the structure is more, when compared to both the water tanks the circular water tank has the maximum drift value. As per 1893:2000 the drift value should not exceed 0.004 the storey height. Figure 3 shows the Storey Drift graph in EQX Figure 4 shows the Storey Drift graph in EQY.

As per IS 1893 (part 1):2002 for regular structure and plan irregular structures static analysis has done because the structures are under $40 \mathrm{~m}$ height and in zone II and for vertical irregular structure dynamic analysis has done because the structures vertical irregular. Here for static analysis earthquake load along $\mathrm{x}$-axis (EQX) is considered and for dynamic analysis response spectrum (RS) is considered.

[Figure 3. Storey Drift in EQX]

[Figure 4. Storey Drift in EQY]

\section{Storey Shear}

Due to seismic and wind force the 
lateral force will act on storey it is known as storey shear. The storey shear will be minimum at top of the structure and maximum will be at bottom of structure. Figure 5 shows the Storey shear graph in EQX Figure 6 shows the Storey Drift graph in EQY. Compared to both the water tanks the rectangular water tank as the maximum storey shear value because, in circular water tank the action is less, where as in the rectangular forces action is more.

[Figure 5. Storey Shear in EQX]

[Figure 6. Storey Shear in EQY]

\section{Storey Stiffness}

Storey stiffness is generally defined as the ratio of storey shear to storey drift. Figure 7 shows the storey drift graph in EQX and Figure 8 shows the Storey drift graph in EQY. Compared to both the water tanks the rectangular water tank as the maximum storey stiffness value in EQX and the circular overhead tank has maximum storey in EQY.

[Figure 7. Storey Stiffness in EQX]

[Figure 8. Storey Stiffness in EQY]

\section{Deflection}

Deflection is defined as the deformation of the structure from original position in the y direction. As per IS 456:2000 the deflection should be within $20 \mathrm{~mm}$. Figure 9 shows the deflection graph in EQY. The result obtain for the both overhead water tank is within the limit. Comparing both overhead water tanks the circular tank as the maximum deflection value of $0.1 \mathrm{~mm}$ and rectangular tank as the minimum value of $0.01549 \mathrm{~mm}$.

[Figure 9 Deflection]

\section{Storey Displacement}

Storey displacement is defined as total displacement of $i^{\text {th }}$ storey with respect to ground. Figure 10 shows and Figure 11 shows the storey displacement graph in $\mathrm{X}$ and $\mathrm{Y}$ direction respectively. Comparing both water tanks the circular water tank as the maximum storey displacement value.

[Figure 10. Storey Displacement in EQX]

[Figure 11. Storey Displacement in EQY]

\section{Base Shear}

The Base shear is defined as expected lateral force on structure base due to the seismic activities. Figure 12 shows the base shear graph. The base shear is more in rectangular overhead water tank of value $31.1601 \mathrm{kN}$ compared to circular water tank value of 29.7162 $\mathrm{kN}$.

[Figure 12. Base shear]

\section{Hoop Tension}

Hoop tension is defined as bottom of the tank fluid pressure. Figure 13 shows the hoop tension. Circular overhead water tank hoop tension is more compared to rectangular overhead water tank, the maximum hoop tension is $63.765 \mathrm{kN}$ for circular water tank and for rectangular water tank the bending moment obtained is $61.312 \mathrm{kN}$.

[Figure 13. Hoop Tension]

\section{Area of Steel}

Circular water tank area reinforcement is more due to the equal distribution of pressure compared to rectangular water tank. Figure 14 shows the area of steel graph. The area of steel is $231.87 \mathrm{~mm}^{2}$ for Circular water tank and for Rectangular water tank the bending moment obtained is $222.95 \mathrm{~mm}^{2}$.

[Figure 14. Area of steel] 


\section{Shear Force Diagram}

The SFD shows the variation in shear force along the beam length. Figure 15 shows the rectangular overhead water tank SFD and Figure 16 shows the circular overhead water tank SFD. The shear force obtained is more for the circular water tank compared to rectangular water tank, the Circular overhead water tank shear force maximum value is $28.7624 \mathrm{kN}$.

[Figure 15. Shear Force Diagram of Rectangular water tank]

[Figure 16. Shear Force Diagram of Circular water tank]

\section{Bending Moment Diagram}

BMD represents the bending moment variation along the member length. Figure 17 shows the rectangular overhead water tank bending moment diagram and Figure 18 shows the circular overhead water tank BMD. The Bending moment obtained is more for the rectangular overhead water tank compared to circular overhead water tank, the maximum BM is $6.213 \mathrm{kN}-\mathrm{m}$ for Rectangular water tank and for Circular water tank the BM is $2.224 \mathrm{kN}$ m.

[Figure 17. Bending Moment Diagram of Rectangular water tank]

[Figure 18. Bending Moment Diagram of Circular water tank]

\section{Axial Force Diagram}

The axial force obtained for rectangular water tank is $1.399 \mathrm{kN}$ and for circular water tank is $9.7101 \mathrm{kN}$. Figure 19 shows the rectangular overhead water tank axial force diagram and Figure 20 shows the circular overhead water tank axial force diagram. Compare to both the water tanks the circular water tank as the maximum axial force.

[Figure 19. Axial Force Diagram of Rectangular water tank]
[Figure 20. Axial Force Diagram of Circular water tank]

\section{CONCLUSION}

The following are conclusion which has been archived from the present study. The analysis and design is done for circular overhead water tank and rectangular overhead water tank for the Zone 2. The circular overhead tank and rectangular over head tank are compared for parameters like storey drift, storey shear, storey displacement, storey stiffness, hoop tension, area of steel, base shear and deflection.

The results obtained after the analysis and design for the parameters are within the limit, and the storey drift of the circular water tank is maximum due to its height, the storey shear of rectangular water tank is maximum due to its shape. The deflection and storey displacement of circular water tank is maximum and the storey stiffness is maximum for the rectangular water tank. The hoop tension and area of steel is more in circular water tank due to equally distribution of pressure.

By this we say that circular overhead water tank is used for the larger capacities and rectangular overhead water tank is used for the smaller capacities and for larger capacity the rectangular tank is not economical.

\section{REFERENCES}

Azgar, M., \& Smruthi, N. R. (2017). Design of Circular Water Tank by Using STAAD PRO Software. International Journal of Scientific Engineering and Technology Research, 6(29), 5642-5650.

Chaduvula, U., Patel, D., \& Gopalakrishnan, N. (2013). Fluidstructure-soil interaction effects on seismic behaviour of elevated water tanks. Procedia Engineering, 51, 84- 
91.

Dogangun, A., \& Livaoglu, R. (2004). Hydrodynamic Pressures Acting on The Walls of Rectangular Fluid Containers. Structural Engineering and Mechanics, 17(2), 203-214, doi: 10.12989/sem.2004.17.2.203.

Hedge, R., G., Y., \& Chawhan, S. (2018). Comparative Study on Rectangular and Circular Water Tank Using STAAD PRO Software. International Research Journal of Engineering and Technology (IRJET), 5(11), 13191323.

IS 456: 2000, Indian Standard: Code for Plain and Reinforced Concrete, Bureau of Indian Standards, New Delhi.

IS 456: 2000, Indian Standard: Plain and Reinforced Concrete - Code of Practice, Bureau of Indian Standards, New Delhi.

IS 875 (part 2): 1987, Indian Standard: Code of practice for design loads, Imposed loads, Bureau of Indian Standards, New Delhi. .

IS 1893 (Part 1): 2002, Indian Standard: Criteria for Earthquake Resistance Design of Structures, Bureau of Indian Standards, New Delhi.

Soroushnia, S., Tafreshi, S. T., Omidinasab, F., Beheshtian, N., \& Soroushnia, S. (2011). Seismic performance of RC elevated water tanks with frame staging and exhibition damage pattern. Procedia engineering, 14, 3076-3087.

Thalapathy, M., R.P., V., P., S., V., S., \& V.S., S. (2016). Analysis and Economical Design of Water Tanks. International Journal of Innovative Science, Engineering, and Technology, 3(3), 602-607. 


\section{Appendix}

\section{List of Tables}

1. Table 1 Dimensions of rectangular water tank .................................................................79

2. Table.2 Dimensions of circular water tank …………......................................................... 79

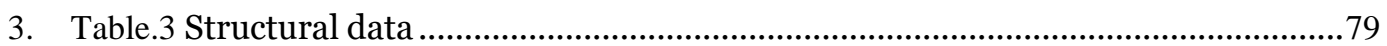

Table 1. Dimensions of rectangular water tank

\begin{tabular}{ll}
\hline Specification & Dimension \\
\hline Volume & 50000 litres \\
Length & $4.5 \mathrm{~m}$ \\
Breadth & $2.5 \mathrm{~m}$ \\
Depth & $5 \mathrm{~m}$ \\
\hline
\end{tabular}

Table 2. Dimensions of circular water tank

\begin{tabular}{ll}
\hline Specification & Dimension \\
\hline Volume & 50000 litres \\
Diameter & $5 \mathrm{~m}$ \\
Depth & $2.6 \mathrm{~m}$ \\
\hline
\end{tabular}

Table 3. Structural data

\begin{tabular}{ll}
\hline Specifications & Dimension \\
\hline Concrete Grade & M30 \\
Steel Grade & Fe 500 \\
Beam & $300 * 450 \mathrm{~mm}$ \\
Column & $300 * 450 \mathrm{~mm}$ (Rectangular Water Tank) \\
Slab & $300 * 450 \mathrm{~mm}$ (Rectangular Water Tank) \\
Wall & $200 \mathrm{~mm}$ \\
& $200 \mathrm{~mm}$ \\
\hline
\end{tabular}




\section{List of Figures}

1. Figure 1. Rectangular Overhead Water 80

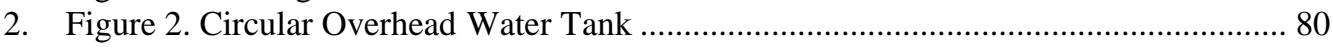

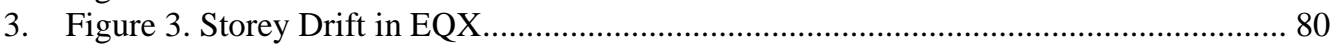

4. Figure 4. Storey Drift in EQY ................................................................................ 80

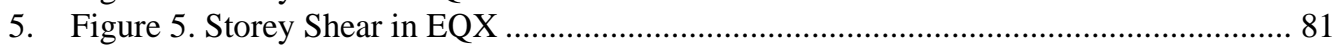

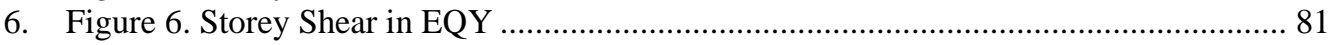

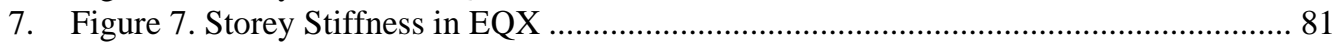

8. Figure 8. Storey Stiffness in EQY …...................................................................... 81

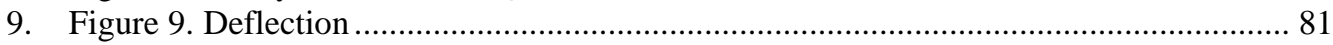

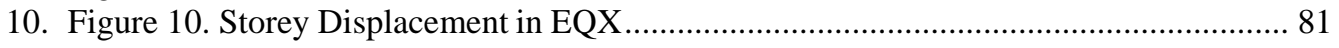

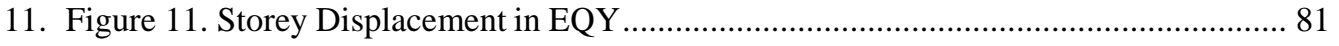

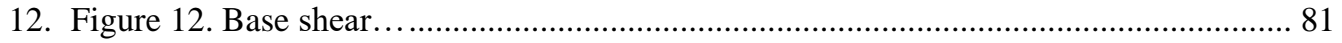

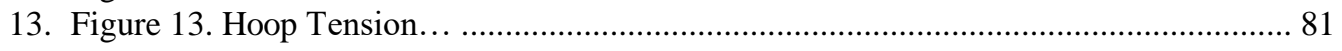

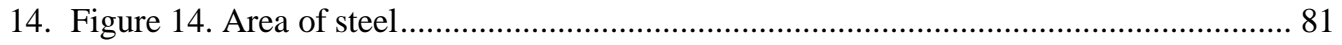

15. Figure 15. Shear Force Diagram of Rectangular water tank ....................................... 82

16. Figure 16. Shear Force Diagram of Circular water tank......................................... 82

17. Figure 17. Bending Moment Diagram of Rectangular water tank ................................. 82

18. Figure 18. Bending Moment Diagram of Circular water tank ..................................... 82

19. Figure 19. Axial Force Diagram of Rectangular water tank ................................... 82

20. Figure 20. Axial Force Diagram of Circular water tank ........................................... 82 
Applied Research on Civil Engineering and Environment (ARCEE) VOL. 02 No. 02, February 2021

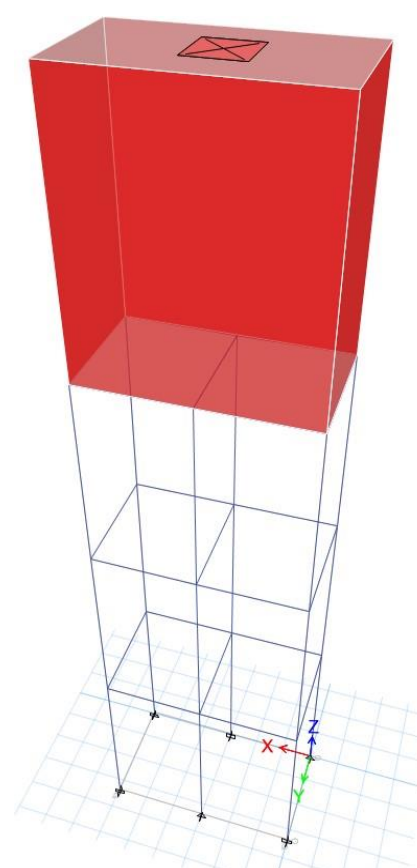

Figure 1. Rectangular Overhead Water Tank

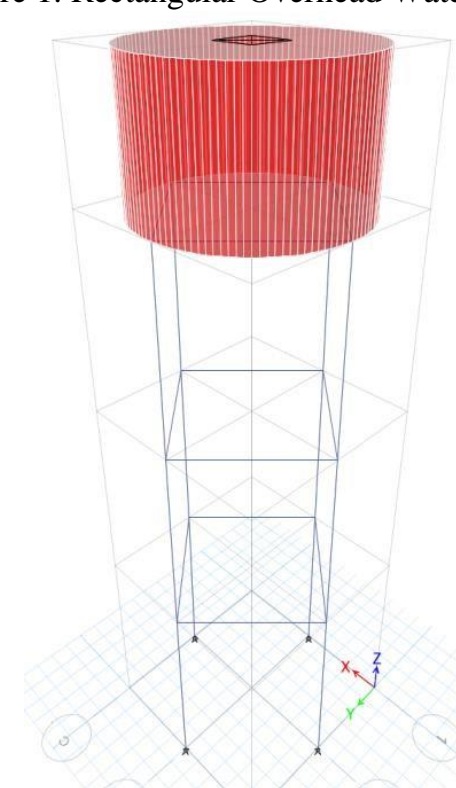

Figure 2. Circular Overhead Water Tank 


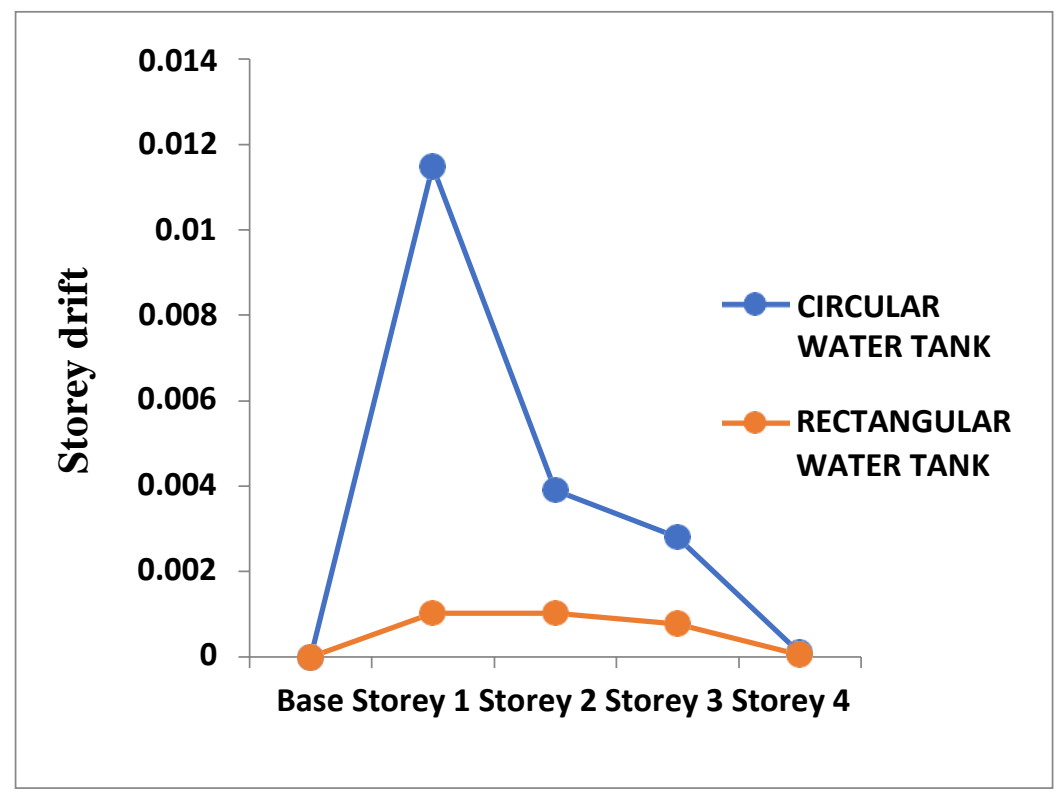

Figure 3. Storey Drift in EQX

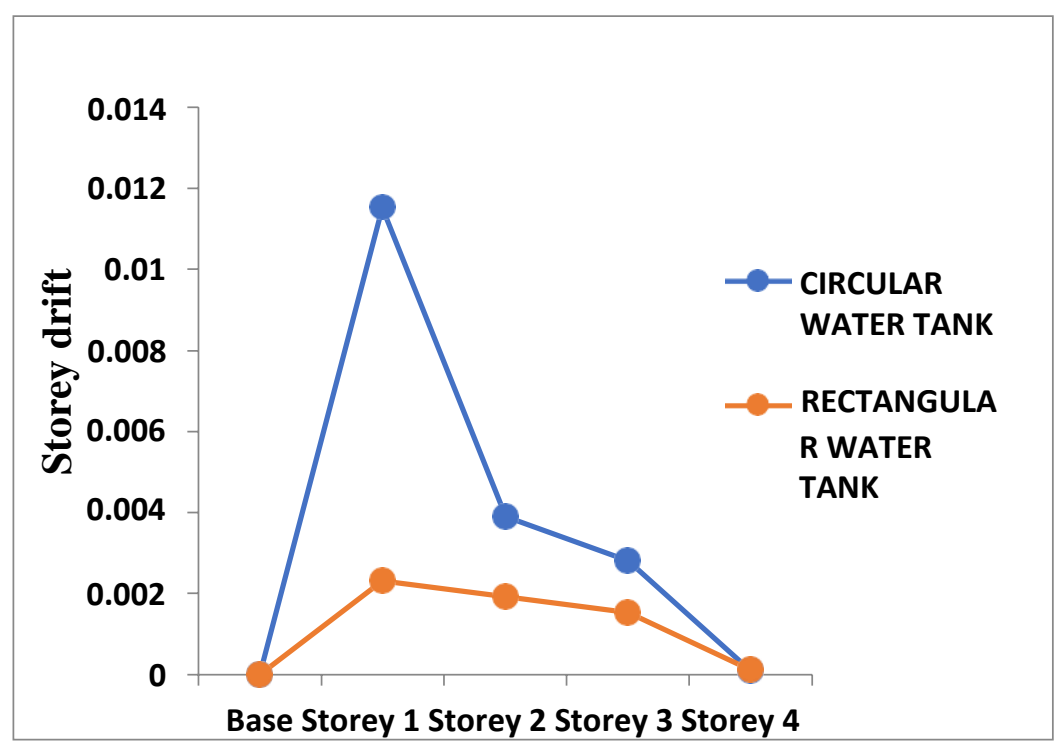

Figure 4. Storey Drift in EQY 


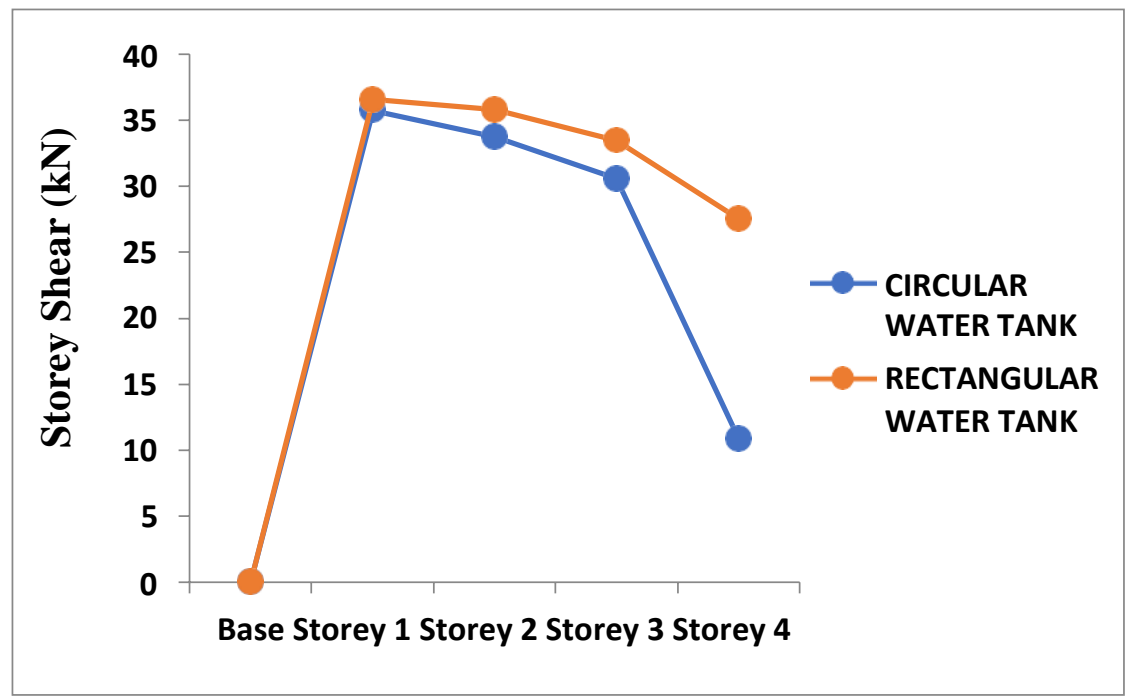

Figure 5. Storey Shear in EQX

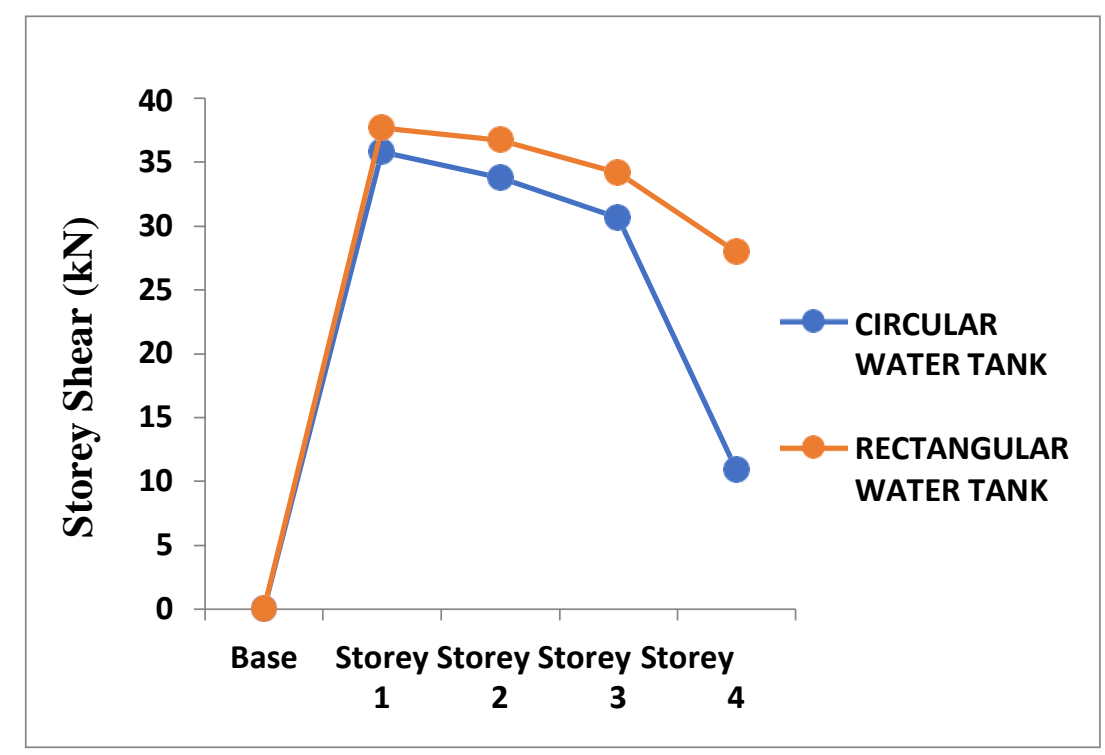

Figure 6. Storey Shear in EQY 


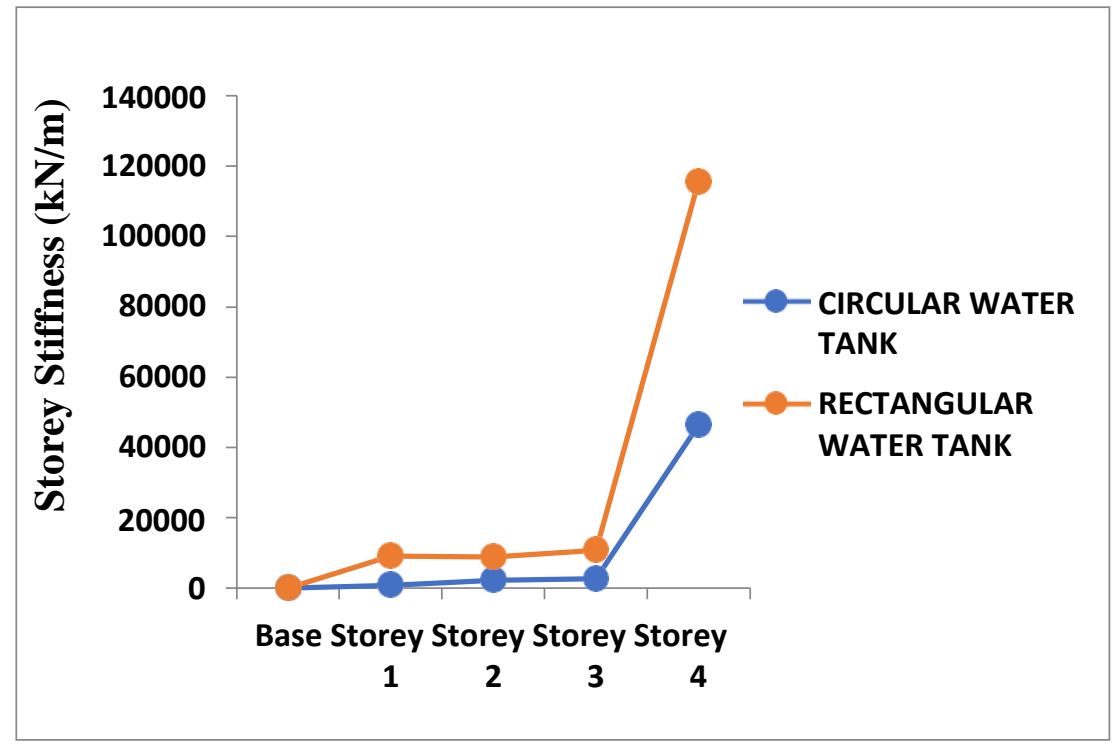

Figure 7. Storey Stiffness in EQX

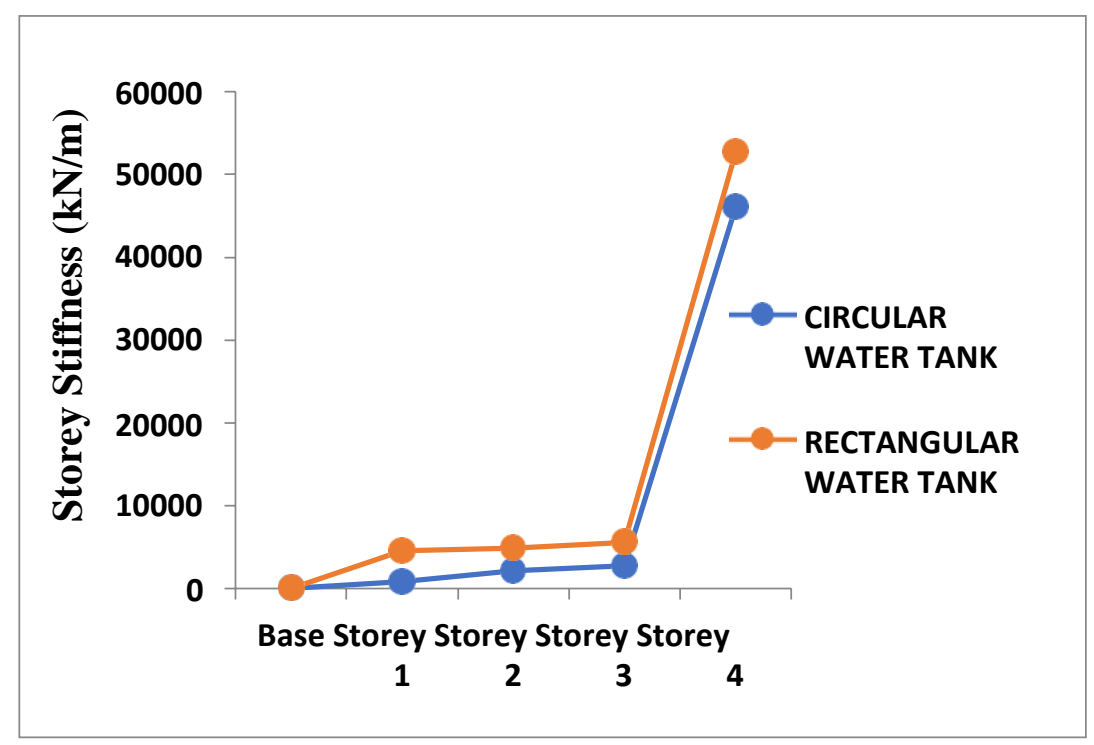

Figure 8. Storey Stiffness in EQY 


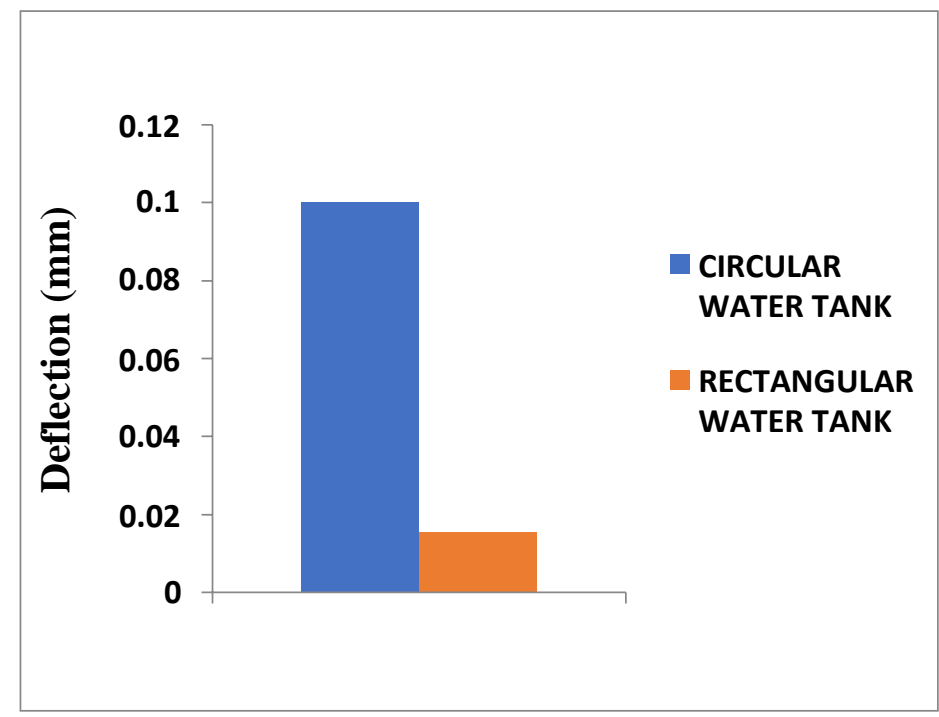

Figure 9. Deflection

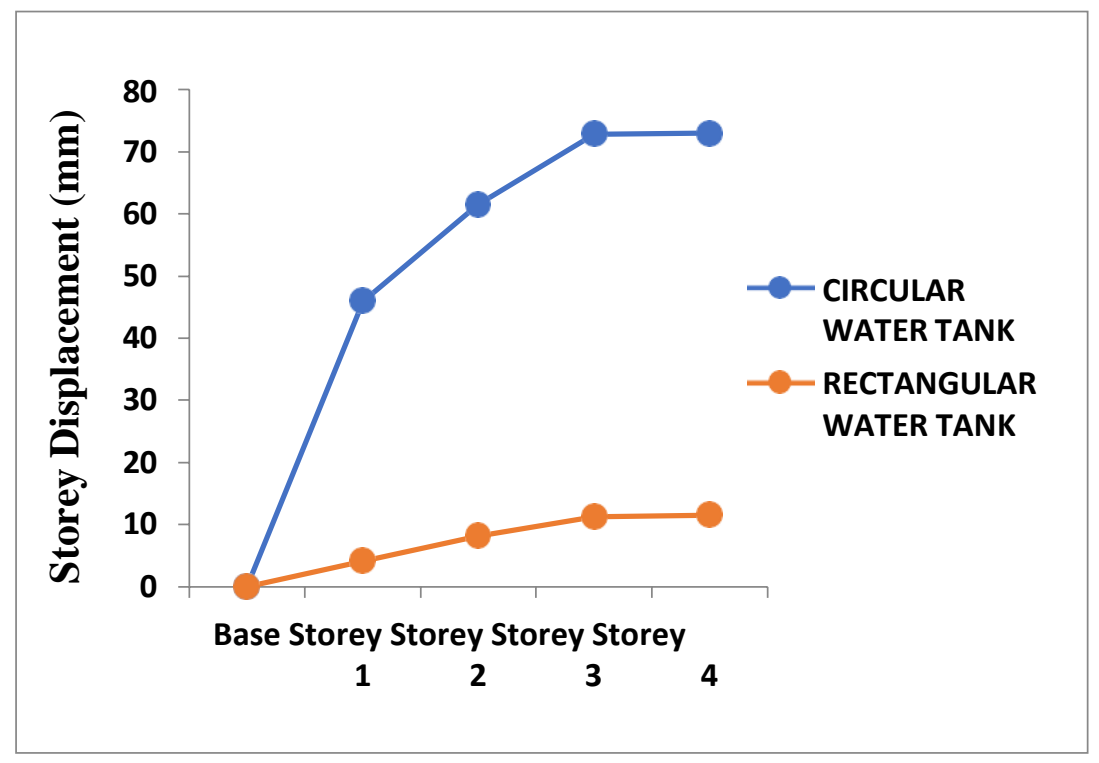

Figure 10. Storey Displacement in EQX 


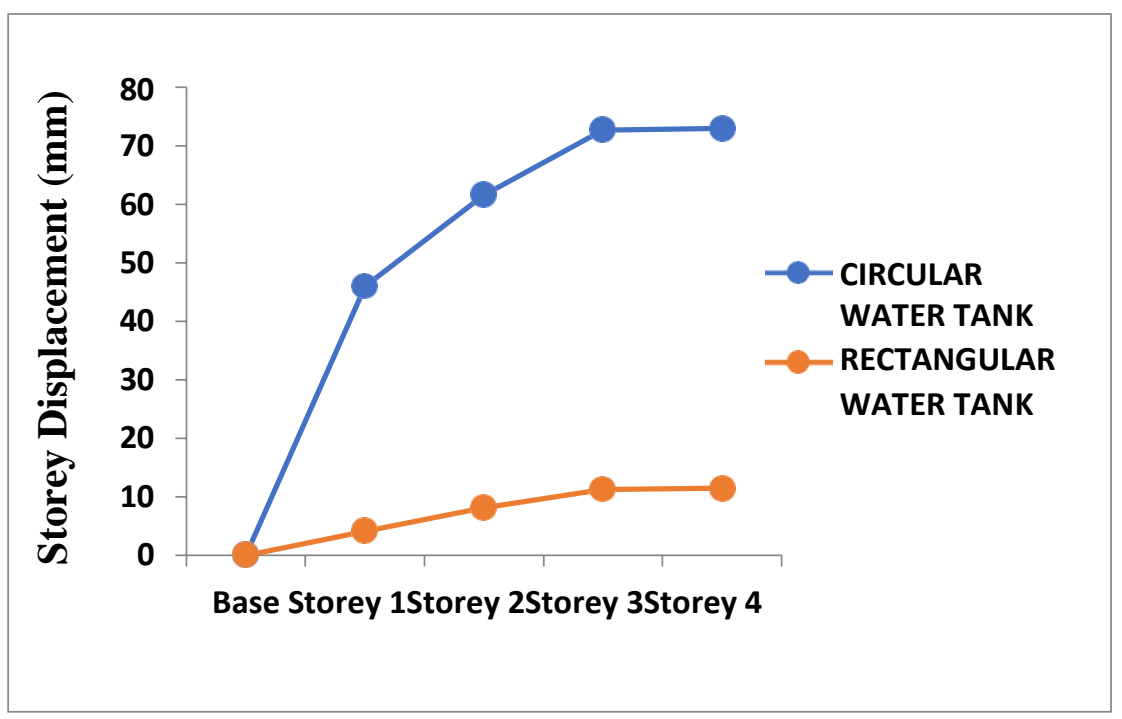

Figure 11. Storey Displacement in EQY

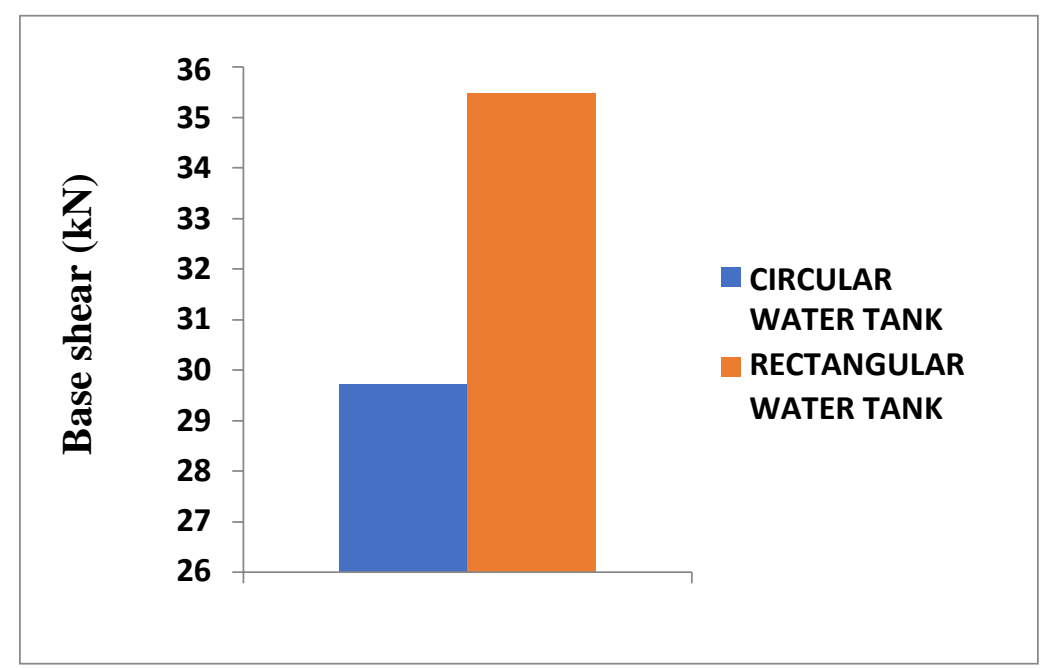

Figure 12. Base shear 


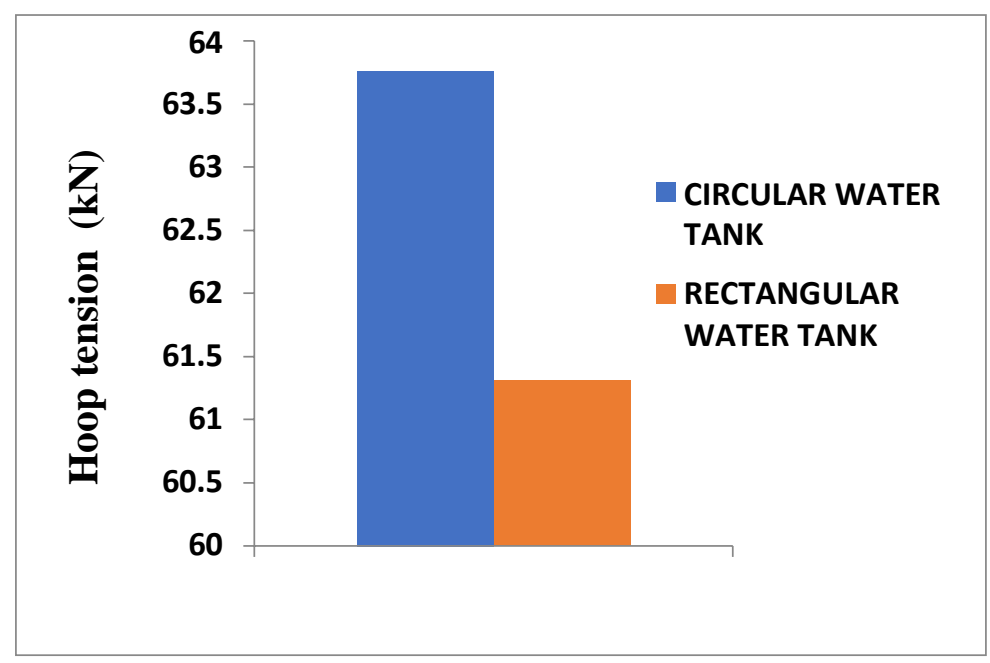

Figure 13. Hoop Tension

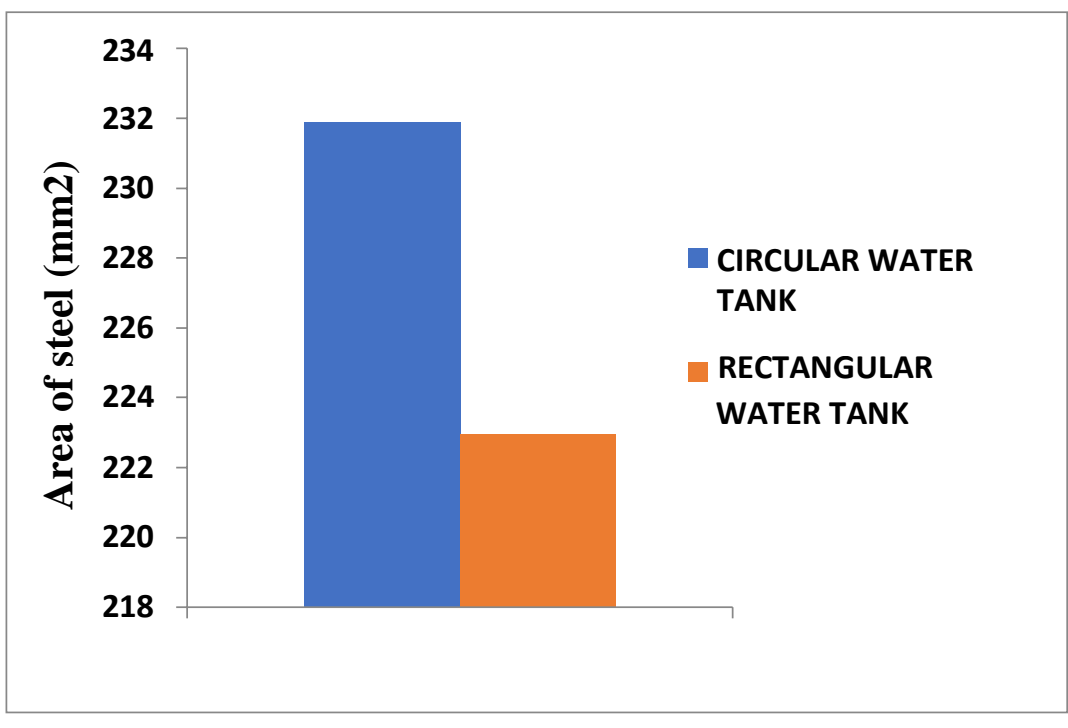

Figure 14. Area of steel 


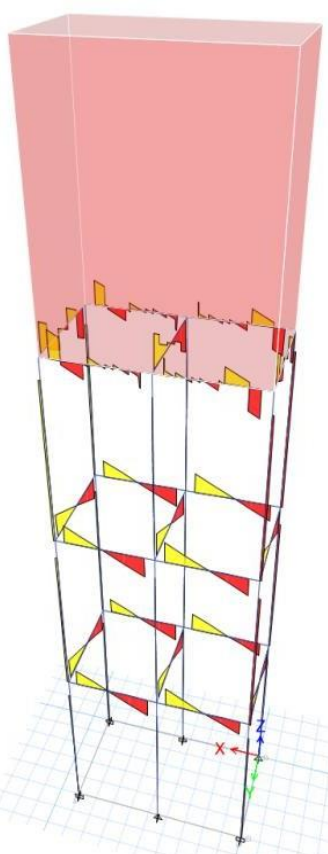

Figure 15. Shear Force Diagram of Rectangular water tank

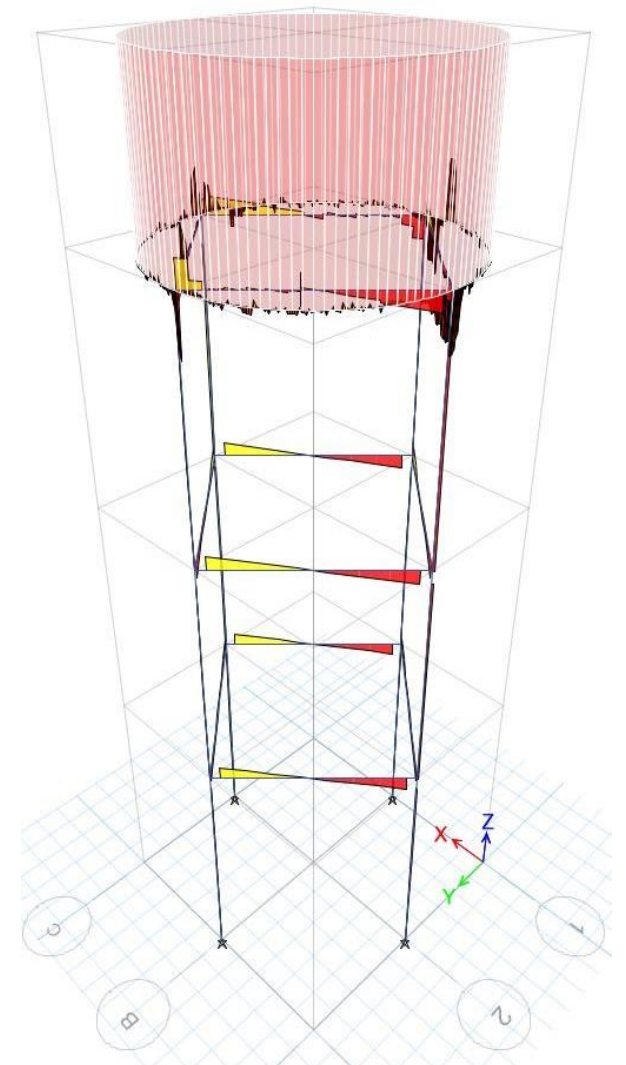

Figure 16. Shear Force Diagram of Circular water tank 
Applied Research on Civil Engineering and Environment (ARCEE) VOL. 02 No. 02, February 2021

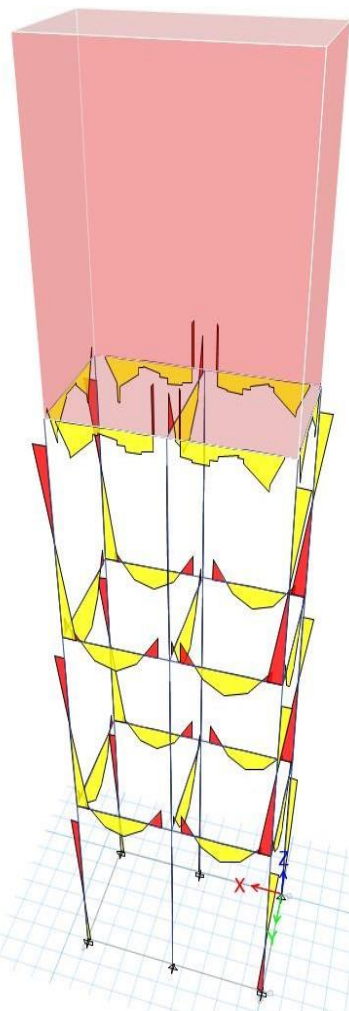

Figure 17. Bending Moment Diagram of Rectangular water tank

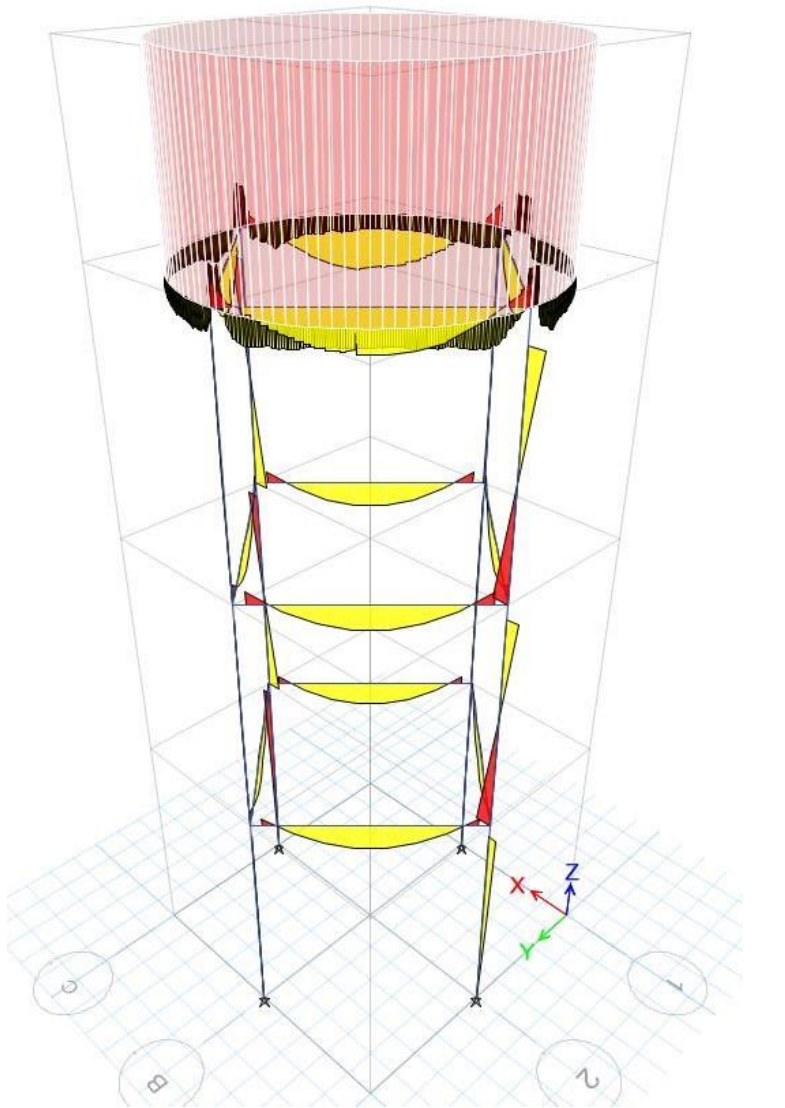

Figure 18. Bending Moment Diagram of Circular water tank 


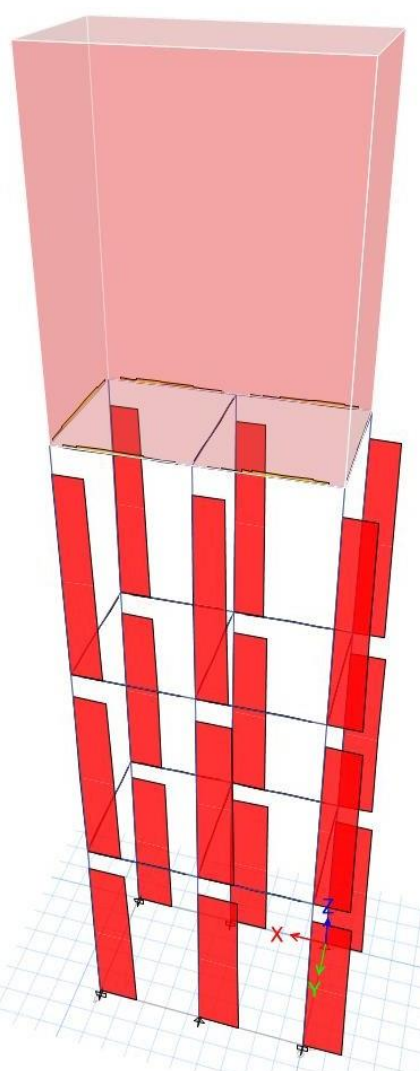

Figure 19. Axial Force Diagram of Rectangular water tank

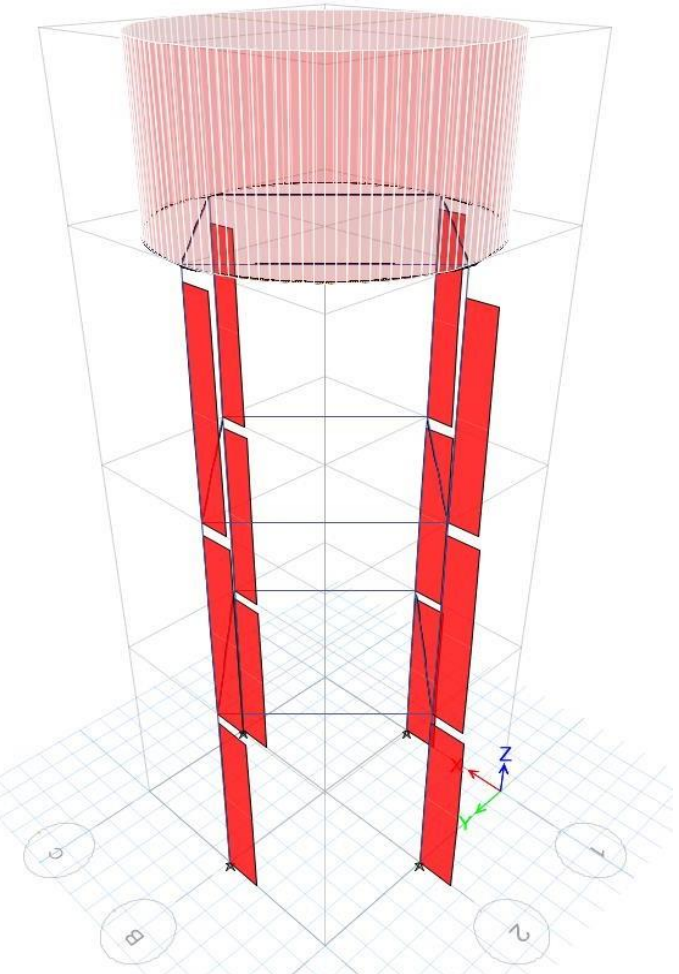

Figure 20. Axial Force Diagram of Circular water tank 